\title{
THE MT. PLEASANT COLLEGIATE INSTITUTE; A STRUGGLE FOR EXISTENCE
}

\author{
By Dr. Louis A. Haselmayer \\ lowa Wesleyan College
}

Iowa Wesleyan College is the successor to the Mount Pleasant Collegiate Institute, the final result of a series of earlier efforts by citizens of the community to found a school. These previous attempts combined legislative actions of territorial governments with local interest. Since a number of the same men were associated with all the efforts, their activities form a somewhat continuous movement.

Iowa became United States Territory in 1803 as part of the Louisiana Purchase. It was sparsely inhabited by several Indian tribes and had its first contact with white men through French-Canadian explorers who sailed down the Mississippi. Unofficial settlement by white men from the east bank of the Mississippi was evident in southeast Iowa as early as a trading post south of the present city of Burlington in 1801 and a settlement in the area of Keokuk in $1820 .^{1}$ In the 1830s the region opened up much more rapidly.

On June 28, 1834 Iowa was made a part of the Territory of Michigan and governed by the statutes of that Territorial Legislature. Two years later on July 4, 1836 Iowa was included in the Territory of Wisconsin and two years after that on June 12,1838 , the Territory of Iowa itself was created with a provisional capital at Burlington. Southeast Iowa was the dominant center of activity at this time.

The settlement of Mount Pleasant antedates the Territory of Iowa, for it was named and platted by Presley Saunders in the fall of $1834 .{ }^{2}$ On Oct. 25, 1836 the First Wisconsin Territorial Legislature defined county lines and the Mount Pleasant region was named Henry County, a name which continues to the present time. ${ }^{3}$ Sufficient persons had taken up residence

\footnotetext{
${ }^{1}$ The History of Henry County, Iowa. Chicago, Western Historical Company, 1879, p. 166.

${ }^{2}$ Ibid., p. 368.

${ }^{3}$ Ibid., p. 174.
} 
in Mount Pleasant between 1834 and 1838 so that the claim of Mount Pleasant to be made the permanent capital of the Territory of Iowa was seriously advanced in November, $1838 .{ }^{4}$ Work was begun on the first Henry County Court House on June 24, 1837 and in 1838 a territorial road from Fort Madison to Trenton, via Mounty Pleasant, was begun. ${ }^{5}$ There are extant records of marriages, court actions and other legal proceedings as early as $1837,{ }^{6}$ and a common school in the cabin of John P. Grantham existed in 1836 or $1837 .{ }^{7}$ The county court house was completed by 1839 ; a county jail was constructed at the same time. ${ }^{8}$ By 1840 there were about 300 inhabitants and an 1846 Directory listed lawyers, physicians, druggists, two hotels, various business establishments and several religious bodies. ${ }^{9}$ Enough population and business warranted the incorporation of Mount Pleasant on Jan. 25, 1842. ${ }^{10}$

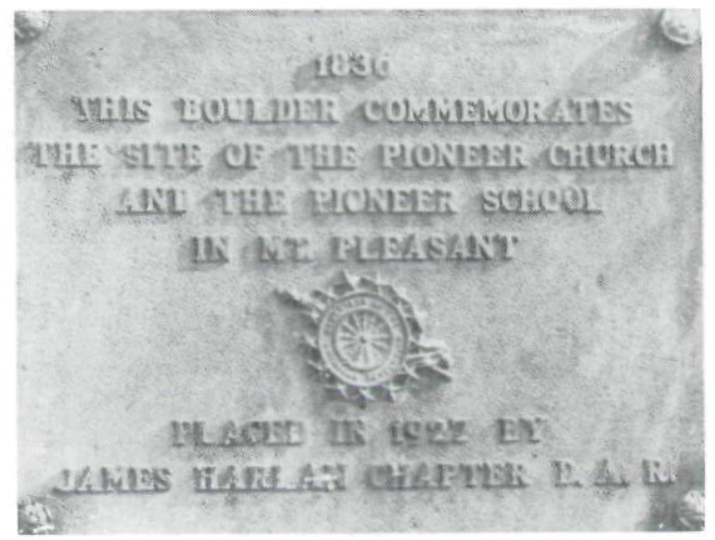

Courtesy Iowa Wesleyan Arcbives

\section{Memorial Marker Commemorates the Site of the Pioneer Church and the Pioneer School (see footnote no. 7).}

${ }^{4}$ Ibid., p. 176 ,

${ }^{5}$ Ibid., p. 389, 391.

${ }^{6}$ Ibid., pp. 396-401.

${ }^{7}$ Ibid., p. 527. The memorial marker, located at West Clay and Van Buren Streets, Mount Pleasant, erected by the James Harlan Chapter of the D.A.R. in 1927, gives the date as 1836 .

${ }^{8}$ Ibid., p. 392.

${ }^{9}$ Ibid., p. 504.

${ }^{10}$ Ibid., p. 573. 
The first religious organization was that of the Methodist Episcopal Church. In the fall of 1835, the Rev. John H. Ruble, a circuit rider from Burlington, preached in the cabin of Presley Saunders and by 1837 there was an organized class of 30 to 40 members under Henry M. Snyder as class leader. ${ }^{11}$ The first Quarterly Conference was held in 1843 with the Rev. Isaac I. Stewart as preacher in charge and John P. Grantham as recording secretary. ${ }^{12}$ The congregation was incorporated in 1842, received a deed of land for a church in 1843 and completed this $35 \times 45$ foot building in December, $1843 .^{13}$

Mount Pleasant in the early 1840 s was a frontier community, but it was stable and growing. It had a nucleus of professional men in law, medicine and ministry who possessed some formal education and were concerned that this education be made available to their children through a local institution.

\section{First Effort to Found School}

The first action to establish a school is found in an omnibus bill of the Territory of Wisconsin on Jan. 19, 1838 in which authority was given for ten seminaries, seven of which were to be located in Iowa. The law reads:

At Mount Pleasant, Samuel Nelson, John H. Randolph, W. L. Jenkins, L. B. Hughes, George W. Patterson, Joseph B. Teas, Vivian C. Steel, Samuel Brazelton, Samuel Hatton [Hutton?], Grender Wilson, Benjamin F. Wallace were authorized to proceed with the opening of a similar institution. ${ }^{14}$

Nothing developed from this legislative permission for a "Mount Pleasant Seminary", but it should be noted that of the eleven men, five would be associated with later efforts to found a school: Samuel Nelson, L. B. Hughes, George W. Patterson, Samuel Brazelton and Samuel Hatton [Hutton].

The next attempt was on Jan. 16, 1840 when the Territorial Legislature of Iowa passed An Act to establish a university

${ }^{11}$ The Story of Methodism in Mount Pleasant, Iowa. Centennial Booklet 1836-1936, p. 4. Cf. also Aaron W. Haines, The Makers of Iowa Methodism. Cincinnati, Jennings and Pye, 1900, pp. 31-32. and Edmund $\mathrm{H}$. Waring, History of the Iowa Annual Conference of the Methodist Episcopal Church. n.p. 1909, pp. 60-63.

${ }^{12}$ The Story . . ., op. cit., p. 5.

${ }^{13}$ Ibid., p. 6.

${ }^{14}$ Laws of the Territory of Wisconsin 1836-1838, pp. 506-509, cited in Clarence Ray Aurner, History of Education in Iowa. Iowa City, State Historical Society of Iowa, III: 6-8. 
at the town of Mount Pleasant, in Henry County. ${ }^{15}$ Mount Pleasant was very much in the Legislature, for on the previous day, Jan. 15, memorials had been introduced to approve turnpikes from Burlington to Fairfiield through Mount Pleasant and from Keokuk to Mount Pleasant. ${ }^{16}$ Mount Pleasant was becoming a transportation center with intersecting eastwest and north-south public roads. The Act stated that the aim was "a university for the purpose of education of youth, the style, name and title whereof shall be the Iowa University." It placed the management under 21 trustees whose names were listed. Here we find the names of J. H. Randolph, Samuel Hutton, Joseph B. Teas who had been involved in the 1838 seminary action, as well as that of E. Killpatrick who would be important in subsequent developments.

The trustees were granted power to receive and hold funds and property, enact by-law and ordinances, appoint a president and professors, set salaries and to "confer such degrees as are usually conferred by universities established for the education of youth." An interesting feature was the provision that "The said trustees may from time to time establish such school or schools preparatory to the organization of said university as they may think proper." The common pattern of a single institution offering both academy and collegiate work, so popular in the middlewest in the 19th century, was clearly envisaged. It is also important to note that the charter referred to "education for youth" and made no explicit or implicit limitation to male students. This was to be a state school under the management of a local group, although there was no provision for public support.

Nothing was effected by this Act and as the state capitol was moved from Burlington to Iowa City in 1842, the Legislature's interest in a university located at Mount Pleasant became less intense.

A lapse of two years occurred until 1842 when the Territorial Legislature of Iowa, meeting in Iowa City, acted on a

${ }^{15}$ Laws of the Territory of Iowa. Burlington, J. M. McKenny, 1840, Cap. 72 , pp. 126-128.

${ }^{16}$ Executive Journal of Iowa (1838-1841). Governor Robert Lucas, edited by Benjamin F. Shambaugh. Iowa City, State Historical Society of Iowa, 1906, p. 309. 
new project from Mount Pleasant. On Tuesday morning, Jan. 4, 1842, Simeon Smead of Henry County gave notice in the House of Representatives that on a subsequent day he would introduce a bill to incorporate “a Literary Institute at Mount Pleasant, in Henry County." ${ }^{17}$ On Friday morning, Jan. 7, Smead introduced No. 37 H. R. File, "A Bill to incorporate the Mount Pleansant Literary Institute." It was read for the first time and the order to print was dispensed with. ${ }^{18}$ The bill was read for the second time on Monday afternoon, Jan. 10. ${ }^{19}$ There was apparently some objection because the House resolved itself into a Committee of the Whole for consideration. After discussion, the Committee which had a bill under consideration, was instructed to "report the same without amendment." But several amendments were made and, upon motion, the bill was referred to a Select Committee of three members for further study.

Seven days later, on Monday, Jan. 17, the Select Committee, under the chairmanship of Asbury B. Porter of Henry County, reported the same bill back to the House ${ }^{20}$ and the next morning, Jan. 18, it was read for the second time. ${ }^{21}$ Considerable debate took place as a motion to refer the bill to the Committee on Incorporations was made, voted upon and lost. Again the House resolved itself into a Committee of the Whole and debate continued. It was finally moved a second time and voted upon to refer the bill to the Committee on Incorporations. On Thursday morning, Jan. 20, the chairman of the Committee on Incorporations reported the bill back with amendments and this was read for the second time on Jan. 21. The bill was ordered to lie upon the table and be printed. ${ }^{22}$ On Tuesday morning, Jan. 25, the bill was reported back, again discussed by the House as a Committee of the Whole and an amendment proposed, ${ }^{23}$ a new Section 10. We do not

${ }^{17}$ Journal of the House of Representatives of the Iowa Legislature. 1841 , p. 78.

${ }^{18}$ Ibid., p. 93.

${ }^{19}$ Ibid., p. 103.

${ }^{20}$ Ibid., p. 126.

${ }^{21}$ Ibid., p. 128.

${ }^{22}$ Ibid., p. 133, 141.

${ }^{23}$ Ibid., p. 153. 
know what the original paragraph stated, but the substitute has considerable interest. "That said Institution shall be under the charge of the Methodist Episcopal Church, but there shall be no religious test for the admission of students to said Institute." ${ }^{24}$ The amendment was put to a vote and lost by a tie of 12 to 12 . The yeas and the nays were requested and the Journal lists the voters by name. The nays were all from counties other than Henry County.

A motion was made and lost to place the bill on the table. Another motion was made and lost to refer it to the Committee on the Judiciary. A third motion was made by the proposer of the bill, Asbury B. Porter, that the House adjourn. This was lost. Mr. Porter then moved that the bill lie on the table until the next Monday and agreement was finally reached. On Monday, Jan. 31, the bill was the order of the day but upon a motion of Mr. Porter, action was postponed until the next Friday. ${ }^{25}$

On Feb. 1, the bill was again read for a second time with a slight amendment proposed and it was ordered engrossed for a third reading on the next day. ${ }^{26}$ This motion passed with 16 yeas and 10 nays. Again the votes were requested and the names are listed in the Journal. Finally on Saturday morning, Feb. 5, the bill was read and voted upon favorably with the same division of 16 yeas and 10 nays and the names recorded. $^{27}$ The bill became law on Feb. 17, 1842. ${ }^{28}$

This surprising wrangle of a month's duration over a charter for an educational institution raises endless questions which cannot be answered from the reports in the House Journal. The vote tabulation does indicate that there was a division along geographical lines, with the major support coming from southeast counties and the major opposition from counties in other sections of Iowa. But it is also apparent from the discussion of Section 10 that the religious affiliation of the

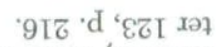

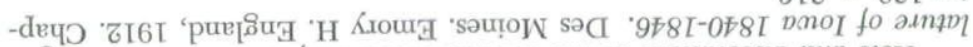

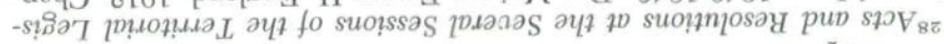

$$
\begin{aligned}
& \text { '80z 'd ' "plq } q I_{L z} \\
& \text { 'T0z 'd ' " p? } q I_{9 z} \\
& \text { 'LLI 'd " p? } q_{\text {s }} \\
& \text { - } p ? q I_{v z}
\end{aligned}
$$


proposed Institute was also involved. But nothing in the debate reveals that there is any relationship between this Literary Institute and the earlier Iowa University proposed for Mount Pleasant.

The bill empowered 16 trustees to operate and manage "The Mount Pleasant Literary Institute" ${ }^{29}$ and defined their legal and financial powers. Memberships in the Literary Institute were to be sold at $\$ 25$ a person, and these members had certain voting rights. The trustees were empowered to appoint "professors, tutors and teachers" and regulate their salaries as well as "fix the price of tuition". The debated Section 10 appears: "No Religious test of Admission. That said institution shall be under the charge of the Methodist Episcopal Church, but there shall be no religious test for the admission of students to said institute." ${ }^{30}$ It was clear that the Literary Institute was to be a school, but it is implied that it could serve other functions, for its funds and properties "shall be faithfully applied, for the benefit of education and science." It would seem that the incorporators had in mind the establishment of some kind of museum similar to the so-called Institutes of Science which existed in other communities during the next decades.

But of even greater importance is the fact that of the 16 incorporators, 5 were men who had been involved in one or more of the previous ventures: E. Killpatrick, Samuel Nelson, L. B. Hughes, G. W. Patterson, and Samuel Brazelton. It was this group that was determined to bring a school into being in Mount Pleasant.

Between Feb. 17, 1842, and March 8, 1843, there is a gap of considerable mystery and in this mystery lies the actual founding date of the eventually successful attempt to begin a school. For at some date after the approval for the Mount Pleasant Literary Institute, 10 of the 16 incorporators, acting with 10 additional Mount Pleasant citizens, framed Articles of Association to establish the Mount Pleasant Collegiate Insti-

${ }^{29} I$ bid., p. 214.

${ }^{30}$ Ibid., p. 216. 
tute. ${ }^{31}$ This document is of purely local origin and is unfortunately not dated. The unresolved question remains as to whether the Collegiate Institute was just another form of the Literary Institute or whether it was a completely new venture started by some of the same men. Since the 1905 Historical Sketch of Iowa Wesleyan University written by Pres. John W. Hancher and the resulting trustee action taken upon his suggestion, 1842 has been regarded as the founding year. ${ }^{32}$ Since the 1942 Centennial History of Iowa Wesleyan College by Dr. Charles J. Kennedy, Feb. 17, 1842, the chartering of the Literary Institute, has been the officially accepted Founders Day. ${ }^{33}$ It is the opinion of this writer that the Kennedy identification of the two institutions is not absolutely firm, but it is also the opinion of this writer that since founding dates are determined on the basis of various criteria and since this date is so formally imbedded in Iowa Wesleyan tradition, one might as well accept it for the future. ${ }^{34}$

\section{Articles of Association}

The Articles of Association declared the purpose of the Mount Pleasant Collegiate Institute, indicated that any person could become a member upon the payment of five dollars "in money, labour, property or building materials", and stated that all donations must be "faithfully applied to the erection and completion of a suitable building designed and to be dedicated for a 'Collegiate Institute." "'35 Five of the incorporators, J. C. Hall, P. C. Tiffany, Samuel Nelson, Nelson Lathrop and Peter Smith, were designated as trustees to handle legal and financial matters. Article Sixth reads: "This institution shall be placed under the patronage and control of the Annual Con-

${ }^{31}$ Historical Sketch and Alumni Record of Iowa Wesleyan University. Mount Pleasant, Iowa, 1905, pp. 14-15. The Incorporators were: John P. Grantham, Ephraim Killpatrick, S. Smith, A. C. Worthing, J. E. Smith, Jesse D. Payne, N. J. Smith, J. C. Hall, William R. Long, John M. Tee, Charles Stoddard, Abram Johnson, N. Munger, Samuel Nelson, Peter Smith, William Thompson, W. Lathrop, George W. Patterson, P. C. Tiffany and George W. Teas.

${ }^{32}$ Ibid., p. 16.

${ }^{33}$ History and Alumni Record of Iowa Wesleyan College. Mount Pleasant, Iowa 1942, p. 13.

${ }^{34}$ Louis A. Haselmayer, The 125th Anniversary History of Iowa Wesleyan College, Mount Pleasant, Iowa, 1967, p. 8.

${ }^{35}$ Historical Sketch and Alumni Record of Iowa Wesleyan University. Mount Pleasant, 1905, pp. 14-15. 
ference of the Methodist Episcopal Church in the bounds of which it is located, said Conference, or the President thereof, having the power to appoint the professors, and a board of visitors." ${ }^{36}$ An extremely close tie with the Methodist Episcopal Church was intended, although at this time there was no Conference in Iowa. Methodist Episcopal work was under the jurisdiction of the Rock River Annual Conference in Illinois and the Iowa Annual Conference did not come into being until 1844. Most of the incorporators were Methodists. Ephraim Killpatrick, John P. Grantham, Nelson J. Smith and Samuel Nelson composed the first board of trustees of the Methodist Episcopal Church in Mount Pleasant on July 11, 1842, ${ }^{37}$ and George W. Teas and Jesse D. Payne were also listed in early Methodist records. ${ }^{38}$ P. C. Tiffany, however, was an Episcopalian and it is possible that the others had different religious affiliations, but the main force was the local Methodist community.

These men also appear prominently in Mount Pleasant affairs. William Thompson was a lawyer and a member of the House of Representatives of the Territory of Iowa; Jesse D. Payne was a physician; P. C. Tiffany was a magistrate and hotel owner; George W. Teas had legal training and engaged in regional political life; John P. Grantham was city treasurer and a member of the council for many years. ${ }^{39}$

The first task before the Incorporators was the raising of funds and the construction of a building. On March 8, 1843, a contract was signed with Aristides Joel Priest Huestis to act as Agent to raise money and supervise building operations. This contract is the first dated document for the Mount Pleasant Collegiate Institute. ${ }^{40}$ Huestis was a New Englander who began his education when he was 25 years old with a year at the Wilbraham Academy, Massachusetts and three years at Connecticut Wesleyan University. ${ }^{41}$ He taught school in New

${ }^{36}$ Ibid., p. 15.

${ }^{37}$ History of Henry County . . ., op. cit., p. 519.

${ }^{38}$ Ibid., p. 518-519.

${ }^{39}$ Ibid., p. 510, 513, 519.

${ }^{40}$ Haselmayer, op. cit., p. 8.

${ }^{41}$ Louis A. Haselmayer, "Wesleyan's First President. Aristides Joel Priest Huestis", The Purple and White, Iowa Wesleyan College, XI, No. 2, May 1967, pp. 8-11. Reprinted from the Mount Pleasant News, March 18, 1967. 
Jersey in 1834-1835 and was later associated with the promotion of the Buckingham Female Collegiate Institute in Virginia. He then moved west to establish a school of his own or become identified with a new school. The exact details of how he became acquainted with the incorporators of the Mount Pleasant Collegiate Instiute are not known and any theories about it are mere speculation. But it would seem that "Huestis arrived in this area on his own, looking for a likely spot to start a school." ${ }^{42}$

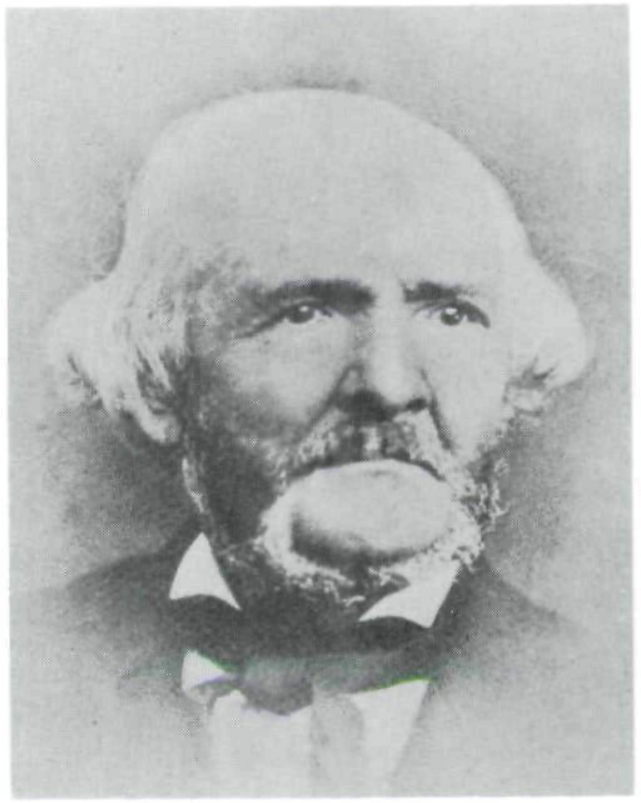

Courtesy Iowa Wesleyan Archives

\section{Aristides Joel Huestis}

Immediate prospects brightened, for on March 11, 1843, a donation of 20 acres of land in four adjoining plots was made to the Institute by John Jones, J. C. Hall, Samuel Brazelton and Peter Smith-all of Mount Pleasant. They were given "with the express understanding that the land is to be occupied and held for a building site for the institution, and that this grant shall be inoperative and void, provided that it should not be used for the purposes aforesaid and the Trustees

${ }^{42}$ Ibid., p. 9. 
within three years from this date erect a substantial building on some part of said donations, which building shall be used and forever appropriated as an Institute of Learning." ${ }^{43}$ Of these donors, J. C. Hall and Peter Smith were Incorporators of the Collegiate Institute. Samuel Brazelton had been connected with the proposed Mount Pleasant Seminary in 1838 and the Mount Pleasant Literary Institute in 1842. John Jones was a newcomer to educational efforts.

Under the leadership of Aristides Huestis, the collection of funds and building work progressed slowly through 1843, 1844 and 1845. Records are extremely inadequate for these years. The Minute Book of the Trustees of the Mount Pleasant Collegiate Institute lacks the first 17 pages and the first dated entry is Oct. 8, 1845. Huestis himself kept a Daybook of accounts and works, but the earliest entries are for 1844. It is possible to gain only a general impression of many small donations, intermittant work on the building and many trips around the region in the interests of the Institute.

Support for the Institute was complicated by rival educational efforts. In the winter of 1841-1842, Samuel Luke Howe started a school in a log cabin, four miles east of Mount Pleasant on the Burlington road, and moved this to the upper story of the log jail in Mount Pleasant in 1842. ${ }^{44}$ In 1844 it was established in the Cumberland Presbyterian Church, and in 1845 moved into the reconstructed Old Mill, three blocks east of the city square on East Monroe Street. ${ }^{45}$ Called for some years The Mount Pleasant High School and Female Seminary, and later Howe's Academy, it had a continuous existence until $1916 .^{46}$

Public education was also projected during this decade as the Henry County Common School Association was organized on Jan. 29, 1844, and school districts set out in $1849 .{ }^{47} \mathrm{~A}$ letter written from Mount Pleasant in 1843 by Dr. Charles Clark to his mother describes the situation as: "No schoolhouse, but two male and one female school; a Methodist col-

${ }^{43}$ Henry County Archives, March 11, 1843.

${ }^{44}$ R. S. Galer, "The Old Mill," The Palimpsest, XII, No. 10, October 1931, p. 384. Cf. Howe's Academy Archives at Iowa Wesleyan College.

${ }^{45}$ Ibid.

${ }^{46}$ Ibid., p. 395.

${ }^{47}$ The History of Henry County, op. cit., p. 433. 
lege is begun." ${ }^{48}$ The promoters of the Mount Pleasant Collegiate Institute did not have a field entirely free of competition.

\section{Collegiate Institute Incorporated}

The next important step was an incorporation for the Collegiate Institute from the Territory of Iowa. This was a procedure far less complicated than the month's struggle in 1842 over the Literary Institute. On Jan. 29, 1844, Mr. William Thompson, one of the Incorporators and a representative from Henry County, gave notice in the House of Representatives that he would introduce the next day, A Bill to incorporate the Mount Pleasant Collegiate and this was done on Jan. $30 .^{49}$ It was read for a second time on Feb. 1, 1844 and it was ordered engrossed for a third reading on Saturday, Feb. 3 when it was passed and sent to the Council. ${ }^{50}$ The Council received the Bill on Feb. 10, and postponed action until Feb. 15 when it was passed and became official. ${ }^{51}$ Iowa Wesleyan observed Feb. 15, 1844 as a founding date for some years.

The Incorporation Act stated:

that the objects and purposes of said incorporation shall be wholly confined to the acquiring of sufficient real estate, erecting buildings, endowing professorships, establishing a library, and sustaining an institution of learning, designed and kept open for the education of all denominations of white citizens. $^{52}$

The remainder of the Incorporation Act dealt with legal arrangements on the holding of funds and properties. There is certainly a striking change from Section 10 of the Incorporation Act of the Literary Institute and the Sixth Section of the Articles of Association of the Collegiate Institute which made the school a corporate part of the Methodist Episcopal Church and this vague statement, "education of all denominations." The phrase about "white citizens" needs to be read in the light

${ }^{48}$ Cited in Olive Cole Smith, Her First Hundred Years. Mount Pleasant, Iowa. Privately printed, 1942. Reprint of 1966, p. 32.

${ }^{49}$ Journal of the House of Representatives of the Sixth Legislative Assembly of the Territory of Iowa. Dubuque, Wilson and Kiesecker, 1844, p. $150,151$.

${ }^{50}$ Ibid., pp. 170-171, 184-185.

${ }^{51}$ Ibid., p. 231, 269.

${ }^{52}$ Acts of Incorporation and Amendment of Iowa Wesleyan University. Burlington, C. Dunham, 1856, p. 3. 
of the year 1844, although additional documents might illuminate the thinking of the persons who used it and any special regional tensions involved. The total item, "education of all denominations of white citizens" was dropped in the Amendment to this Act on Jan. 25, 1855 which formed the charter of the later Iowa Wesleyan University. At that time subsequent developments made it necessary to spell out in detail the relationship of the Institute to the Iowa Annual Conference of the Methodist Episcopal Church. ${ }^{53}$

The patronage of the Methodist Episcopal Church had been included in the previous Incorporation Acts and the trustees of the Collegiate Institute made early efforts to obtain this. On Aug. 14, 1844, at the first Iowa Annual Conference, meeting in Iowa City, Aristides Huestis presented a request which was signed by William Thompson, Nelson Lathrop, John P. Grantham, P. C. Tiffany and W. J. Coalter for the trustees. $^{54}$ On Aug. 19 a committee reviewed this report which stated that the Institute had 20 acres and a building in process of erection which would be worth $\$ 5,000$ upon completion. The Committee rejected the request because of a previous promise to extend patronage to the recently opened Iowa City College under the presidency of James Harlan, on the ground that it would be inexpedient for the Conference to accept another institution. ${ }^{55}$ This James Harlan later became an important president of the Mount Pleasant Collegiate Institute in 1853. But the meeting place in Iowa City for this Conference meant that the group was subject to certain pressures from the local interests. ${ }^{56}$

Huestis presented the cause again at the 1845 Annual Conference on Sept. 5 and a committee for a second time rejected it in favor of the Iowa City College, but stated specifically,

that the trustees of Mt. Pleasant Collegiate Institute have not, in the opinion of the Committee, presented such documents as would place the institution entirely under the control of the Iowa Annual Conference. ... .57

${ }^{53}$ Ibid., p. 6.

${ }^{54}$ Minutes of the Iowa Conference of the Methodist Episcopal Church. Annual Sessions 1844 ... 1853. Burlington, 1916, pp. 5-7.

${ }^{55}$ Ibid., p. 14.

${ }^{56}$ Haselmayer, 125th Anniversary History, op. cit., p. 10.

${ }^{57}$ Minutes of the Iowa Conference . . ., op. cit., pp. 23-24. 
But the 1845 Conference did appoint a Committee on Sept. 8, consisting of Andrew Coleman and William Simpson, to visit the Institute. ${ }^{58}$ The Committee reported to the 1846 Conference, on Sept. 5, on a proposed agreement between the Mount Pleasant Collegiate Institute and the Iowa Conference in which the completed Institute building was described in detail. The Committee stated that "we entertain feelings of kindness towards it, and think it deserving of respect and approbation . . yet our situation as a Conference, we think, would for the present render it inexpedient for us to take under our direct patronage." ${ }^{59}$

The 1847 Annual Conference was held in Mount Pleasant and the delegates had a first hand opportunity to inspect the Institute, but there was no action proposed and the same was true for the 1848 Annual Conference. At the 1849 Annual Conference, the Committee on Education proposed, Aug. 10, that the Iowa Conference accept the Mount Pleasant Collegiate Institute as a Conference school, that the presiding elder of the Burlington District together with the preachers at Burlington, New London, Fairfield and Mount Pleasant be appointed to consumate the agreement and that other legal arrangements for representation on the board of trustees be effected. ${ }^{60}$ On Aug. 13 a Visiting Committee to the Institute was appointed. ${ }^{61}$ By 1849, the Iowa City College was defunct, the Mount Pleasant Collegiate Institute became an Iowa Conference institution and the Methodist Episcopal affiliation was formally established.

The work on the building progressed slowly. But by November, 1845, the end was in sight, after two years and nine months of work by Aristides J. Huestis. On Nov. 11, 1845 the Board of Trustees voted:

Resolved by the Board of trustees that we deem it expedient to elect a faculty and open a school on the first Monday in January next. ${ }^{62}$

Aristides J. Huestis was elected president and professor of natural and moral sciences and belles lettres and Johnson Pierson was elected professor of ancient languages and literature.

${ }^{58}$ Ibid., p. 32.

${ }^{59}$ Ibid., pp. 48-51.

${ }^{60}$ Ibid., pp. 48-51.

${ }^{61}$ Ibid., p. 115.

${ }^{62}$ Minutes of the Board of Trustees, Nov. 11, 1845. 
Rates of tuition were set at $\$ 12$ per annum for the elementary work, $\$ 16$ per annum for the more advanced, and $\$ 20$ per annum for the highest course. The faculty was empowered to draw up rules for students, subject to the approval of the board. The salaries were to include the use of the building and premises and the income from tuitions. The scholastic year was set at ten months in two divisions or terms.

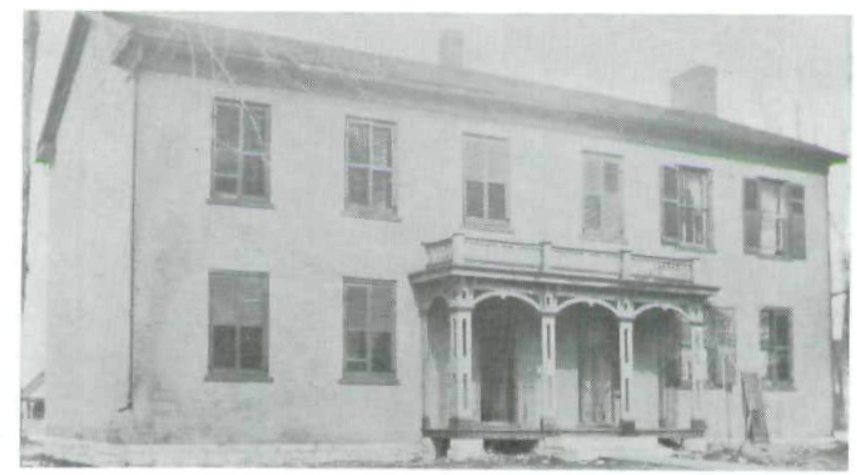

Courtesy Iowa Wesleyan Arcbives

Pioneer Hall

The Institute building, still in use as Pioneer Hall, was described in prospect in a report to the Iowa Annual Conference on Aug. 19, 1844 as

... a good brick building, $28 \times 54$ feet, 2 storeys high ...

the whole valued at $\$ 5,000 \ldots{ }^{63}$

Upon completion, it was described to the Conference on Sept. 5,1846 as

. . . a substantial brick edifice, of academic dimensions, well built and furnished with desks for 140 students in the male and female departments, room for library, apparatus and recitations and four resident rooms, forming a very comfortable residence for the president of the institution, or such other purposes as the trustees may direct. ${ }^{64}$

These rooms on the second floor were occupied by Mr. and Mrs. Aristides Huestis and Mr. and Mrs. Johnson Pierson during the first years of the Institute's existence.

The second member of the faculty, Johnson Pierson, was a native of Virginia who moved to Burlington, Iowa, with his family in 1835 . He was a graduate of the first class of Mc-

${ }^{63}$ Minutes of the Iowa Conference . . ., op. cit., p. 14.

${ }^{64}$ Ibid., p. 50. 
Kendree College, Lebanon, Ill., in 1841. He served as principal of the Mt. Vernon Academy, Ill., from 1841-1845 when he became the first professor at the Mt. Pleasant Collegiate Institute, remaining there until 1849 when he returned to Burlington for a career in journalism and business. He died in St. Louis in 1907 at the age of 93. In 1905 Iowa Wesleyan conferred upon him an honorary Ped.D. on the occasion of the Sextennial of the University. ${ }^{65}$

Mrs. Johnson Pierson assisted with the teaching and on Sept. 22, 1846, Mr. C. A. Olney was selected as professor of mathematics for the ensuing year. ${ }^{66}$ For him we have no further information.

No catalog was published until 1854, but it is clear from the tuition rates set by the trustees that only elementary and academic work were offered. Three levels are distinguished: I, "The Elementary Branches such as Orthography, Reading, writing and the first part of Arithmetic"; II, "The more advanced English Studies, such as the higher course in Arithmetic, modern Geography, English Grammar written composition and Natural and moral philosophy"; III, "the highest course of English studies such as Algebra, Geometry, Plain and Spherical Trigonometry, Astronomy, Ancient Geography, Logic, Rhetoric and Ancient Languages." ${ }^{67}$ All of this is standard except possibly for Logic and certainly the "Natural and moral philosophy" indicates a specific church emphasis in the curriculum.

There is no record of students available until 1853 and the enrollment figures would be impossible to estimate, although it is a safe guess that the students were all children of Mount Pleasant residents.

Very skimpy records for the next years, chiefly minutes of the board of trustees, indicate that the Institute was regularly plagued by financial problems, the need for constant repairs to the building and requests for additional equipment. The students in the 1840s were as indifferent to school property as they are today.

${ }^{65}$ Biographical Review of Des Moines County, Iowa. Chicago, Hobart Publishing Company, 1905, pp. 1034-1035. Alumni File of McKendree College and Archives of Iowa Wesleyan College.

${ }^{66}$ Minutes of Trustees, Sept. 12, 1846.

${ }^{67}$ Ibid., November 11, 1846. 
On April 12, 1847, it was decided to shorten the summer, now called the spring, term to four months instead of five, a decision which was determined by a rural community with need for farmer workers. ${ }^{68}$ On April 22, 1847 a committee of trustees inspected the rooms of the faculty, Huestis was appointed an agent to obtain subscriptions "to liquidate demands against the Institute," ${ }^{9}$ and it was voted to find living quarters outside the Institute "for one of the families." On March 11, 1848, the trustees appointed a committee to attend the annual examinations and to give the results publicly in "one or more public prints." "7o On March 18, 1848 Huestis was again commissioned as an agent for special fund raising and was promised half of the proceeds. ${ }^{71}$ It was decided to enclose the Institute grounds with fencing at the same meeting. The need of additional or more modern equipment soon became apparent for it was reported to the trustees on Sept. 14,1848 , that "there seems to be a disposition existing among some of the older students not to return to the Institute unless there be better accommodations for them in the ensuing term."72 It was resolved "to adopt some measures by which the large room be seated and made ready for the reception and accommodation of pupils" and that they "undertake the seating of said east room of the Institute for this purpose". ${ }^{73}$

In the fall of 1848 Huestis made a preaching tour of the East to collect funds; he reported on the results at a trustees' meeting on Nov. 15, 1848. He collected a total of \$1013.79; after his expenses and honorarium were deducted and the claims against the Institute met, there remained a balance for the future of $\$ 36.78 .^{74}$

Aristides Heustis found time for local politics and in 1847 was involved behind the scenes in promoting the campaign of Judge Charles Mason of Burlington for the position of State Superintendent of Public Instruction. The rival candidate was James Harlan of Iowa City, formerly president of the Iowa

${ }^{68}$ Ibid., April 12, 1847.

${ }^{69} \mathrm{Ibid}$., April 22, 1847.

${ }^{70}$ Ibid., March 11, 1848.

${ }^{71}$ Ibid., March 18, 1848.

${ }^{72}$ Ibid., September 14, 1848.

${ }^{73}$ Ibid.

${ }^{74}$ Ibid., November 15, 1848. 
City College. Harlan came to Mount Pleasant in March 1847, in some annoyance at the Huestis' tactics, and finding a barn raising in progress made it the occasion for a public debate with Huestis on the subject. ${ }^{75}$ There can be no doubt that this appearance in Mount Pleasant by James Harlan helped to impress his personality upon the local trustees who would later call him to head the Collegiate Institute.

During the year 1847-1848 Huestis was stricken with some disease which may have been poliomyelitis and on Feb. 24, resignation of Huestis, the trustees approached Lewis Dwight with an offer of a teaching position for the summer. ${ }^{77}$ The contract with Dwight was settled on April 1. ${ }^{87}$ He was appointed as a teacher only.

Johnson Pierson had managed the affairs of the Institute for the several months, including the oversight of the new seating in the east room, but he was also planning to resign and he requested a recommendation from the trustees on March 15, 1849 , he resigned the presidency. ${ }^{76}$ He shortly after joined a wagon train to California and settled in Humbolt Bay where he was successful in county education, local and state politics. Never returning to Mount Pleasant, he died in Humbolt Bay on March 14, 1883.

The years 1849-1853 were times of crisis in which the Collegiate Institute had a succession of leaders, financial troubles and periods in which it ceased operation altogether. Upon the 1849. ${ }^{79}$ The Rev. Joseph McDowell, minister of the Methodist Episcopal Church in New London, was employed as agent to raise funds and as president of the faculty. ${ }^{80}$

Joseph McDowell, who served 1849-1850, was not college trained but had been a teacher in the common schools in Pennsylvania. He had been a preacher in the Methodist Episcopal Church since 1814 in Pennsylvania, Ohio, and Illinois,

${ }^{75}$ Johnson Brigham, James Harlan. Iowa City, The State Historical Society of Iowa, 1913, pp. 48-49.

${ }^{76}$ Haselmayer, "Iowa Wesleyan's First President", op. cit., p. 10. Minutes of Trustees, February 24, 1849.

${ }^{77}$ Minutes of Trustees, February 24, 1849.

${ }^{78}$ Ibid., April 10, 1849.

${ }^{79}$ Ibid., March 15, 1849.

${ }^{80}$ Ibid., April 19, 1849. Cf. for biography, Louis A. Haselmayer, "Joseph McDowell 1849-1850", The Mount Pleasant News, March 25, 1967. 
and had just entered the Iowa Annual Conference. During the years 1837-1848 he had been closely associated with the development of Ohio Wesleyan University, Delaware, Ohio.

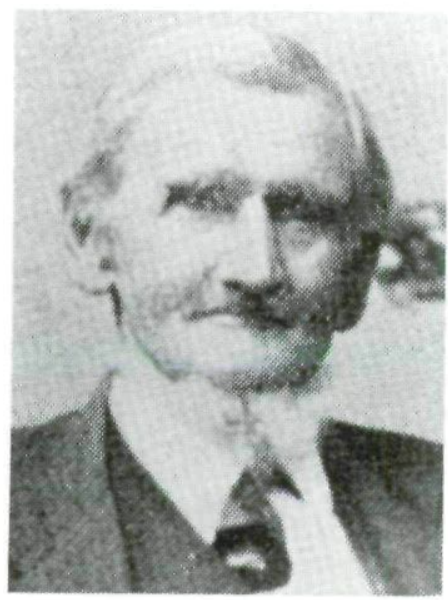

Courtesy Iowa Wesleyan Archives Joseph McDowell

Lewis Dwight, on the other hand, received a B.A. from Connecticut Wesleyan University in 1837 and an M.A. from McKendree College, Lebanon, Ill., in 1840. He had served as principal of the Mt. Vernon Academy, Ill., 1838-1841, as the predecessor of Johnson Pierson; at the Edwardsville Academy, Ill., in 1843 and as principal of the High School in Payson, Ill., in 1843-1848. ${ }^{81}$

McDowell and Dwight prepared the successful approach to the Iowa Annual Conference in September, 1849, which obtained the Conference patronage. The trustees' minutes for the year are filled with the detailed, legal implementation of this relationship. Joseph McDowell resigned the presidency in the summer of 1850, although he remained in the area for many years as a minister and continued his interest in the school.

Lewis Dwight was authorized on Aug. 7, 1850 "to use our Institute and continue his school during the winter or until otherwise instructed." ${ }^{2}$ An advertisement placed in the Iowa

${ }^{81}$ The Alumni Register of Wesleyan University, 1911, Middleton, Conn. Iowa Wesleyan Archives.

${ }^{82}$ Minutes of Trustees, August 7, 1850. 
Free Democrat, Mount Pleasant, Oct. 12, 1849, and which was still running in the issue of Feb. 26, 1850, stated that the school had just recently ". . . passed under the control of the Methodist Episcopal Church" and that "The preparatory department only is at present in operation". The session had started Nov. 12, 1849. In an attempt to draw students from beyond the limits of the town, the announcement noted that "Good board may be obtained convenient \& on reasonable terms." ${ }^{3}$ The Minutes of the 1850 Iowa Annual Conference refer to the Mount Pleasant Collegiate Institute, but the Report on Education which would have had more information is unfortunately listed among "Lost Reports". ${ }^{4}$

On Aug. 21, 1850, the trustees elected the Rev. R. H. Harrison to solicit funds and he received a Conference appointment for this purpose. ${ }^{85}$ Plans were made at this meeting to carry out improvements such as the fence enclosure. The scanty provisions made for previous presidents was on the minds of the trustees for they voted that

... if we can obtain a regular minister from another Conference that we as a board of trustees pledge ourselves to secure him a regular salary as a Methodist preacher and a reasonable support for his family ... also his expense of moving. ${ }^{86}$

A committee was appointed to write the Rev. William F. Stewart of the Ohio Conference. It was voted to repair the buildings as soon as possible and arrangements were made to discontinue the services of Lewis Dwight as teacher.

Resolved that the discontinuance of a school in the institution

building is not from any distrust in the competency of Bro.

Dwight but because we think it inexpedient at present for a

school to be taught in said building by anyone. ${ }^{87}$

The negotiations with William F. Stewart apparently were unsuccessful but the trustees did elect as president, on Oct. 16, 1850, the Rev. Alexander Nelson of the Ohio Conference who assumed direction of the school ${ }^{88}$ and classes were resumed on Jan. $8,1851 .^{89}$

${ }^{83}$ Iowa Free Democrat, February 26, 1850, p. 4. Copy in Iowa Wesleyan Archives.

${ }_{84}^{84}$ inutes of the Iowa Conference, op. cit., p. 141.

${ }^{85}$ Minutes of Trustees, August 21, 1850; Minutes of the Iowa Conference, op. cit., p. 142.

${ }^{86}$ Minutes of Trustees, August 21, 1850.

${ }^{87}$ Ibid.

${ }^{88}$ Ibid., October 16, 1850.

${ }^{89}$ Ibid., January 21, 1851. 
Alexander Nelson had attended Norwich University, Vt., taught at Norwalk Seminary, Ohio, 1839-1841, had been president of the Worthington Female College, Ohio, 1841-1846, had received an honorary M.A. from Ohio Wesleyan University in 1846 and had entered the ministry of the Methodist Episcopal Church in the same year. ${ }^{90}$ Nelson and his wife did the teaching for the semester and it is interesting to note that in the tuition rates one additional subject appears in the curriculum: modern languages. But Nelson resigned the presidency on June 26, 1851, although his back salary was not finally paid until Aug. 15, 1851-and the trustees had to borrow $\$ 100$ to make up the full amount. ${ }^{91}$ Nelson returned to the Ohio Conference but did not loose his ties with Mount Pleasant for he was granted an honorary D.D. by Iowa Wesleyan in 1861.

The Report to the 1851 Iowa Annual Conference on Aug. 11 refers "to the entire failure of the agency of the Mt. Pleasant Collegiate Institute, during the past year" and recommends that

no attempt be made to sustain a school in the above mentioned institute until such improvements be made upon the property as will render it practicable to continue a school at all seasons of the year: the improvements to which we allude are such as fences, plank walks, outhouses etc. ${ }^{92}$

The Conference appointed the Rev. Henry Clay Dean as Agent for the coming year and urged greater Conference financial support.

An unsuccessful attempt was made by the trustees on Aug. 27, 1851 to obtain James Harlan of Iowa City as agent and they voted that a teacher be hired as soon as possible so that "a school will commence in the institute as early as the 1st of November next." ${ }^{\prime 3}$ But on Sept. 24, 1851 the trustees were still looking for both an agent and a teacher. ${ }^{94}$ Additional problems were raised because of the activities of the agent for the previous year, the Rev. R. H. Harrison, whose bookkeeping

${ }^{90} \mathrm{Cf}$. for biography, Louis A. Haseymayer, “Alexander Nelson 18501851”, The Mount Pleasant News, March 25, 1967.

${ }^{91}$ Minutes of Trustees, June 26, August 15, 1851.

${ }^{92}$ Minutes of the Iowa Conference. . ., op. cit., pp. 60-61.

${ }^{93}$ Minutes of the Trustees, August 27, 1851.

${ }^{94} \mathrm{Ibid}$., September 24, 1851. 
and public impression were apparently not above reproach. ${ }^{95}$ The Institute, however, remained closed during the entire academic year 1851-1852. A letter written in 1896 by the Rev. W. C. Shippen, recalling his boyhood in Mount Pleasant, gives a vivid picture.

During the winter of 1851-2 I attended school at Howes Academy, the I. W. U. not being in session that year. The small brick structure, called a college seemed far out on the prairie and looked like a somber monument of premature ambition for sparse settlement and limited church membership and finances. ${ }^{96}$

On April 14, 1852 the problems of an agent, a teacher and liabilities were still before the trustees, ${ }^{97}$ and on April 15, 1852 the Harrison case was still being considered again and a report planned for submission to the Conference. ${ }^{98}$ During the summer, efforts were continued without avail. The Report to the Iowa Annual Conference on Oct. 1, 1852 stated:

The Collegiate Institute at Mt. Pleasant has been resting in a state of inglorious ease during the past year. It is true that efforts have been made recently to employ a teacher and reopen the Institute; but without success. The value of our property there is supposed to be somewhere between five and six thousand dollars; and our liabilities about $\$ 300$ with nothing reliable to liquidate the same. In view of redeeming the Institution from its embarrassaments, and to put it in successful operation, we present the following resolutions for your adoption.

These included the appointment of the Rev. James McDonald as principal and one of three nominees as agent. ${ }^{99}$

On Oct. 18, 1852 the trustees engaged James McDonald as principal and the Rev. Isaac I. Stewart as agent and decided "to employ a female teacher when they deem it expedient.” ${ }^{100}$ Miss M. M. Sackett was later engaged. ${ }^{101}$ On Oct. 19, 1852 it was voted to prepare circulars with information about the institute for distribution, ${ }^{102}$ but if such were printed, none

${ }^{95} \mathrm{Ibid}$. This apparently was what the Conference of 1851 had in mind in the Report on the "entire failure of the agency". Harrison was disciplined by the 1851 Conference. Cf. Minutes, op. cit., pp. 160-161.

${ }_{96}^{96}$ Letter of W. C. Shippen to W. O. Stoddard, November 20, 1896 in Iowa Wesleyan Archives.

${ }^{97}$ Minutes of the Trustees, April 14, 1852.

${ }^{98}$ Ibid., April 15, 1852.

${ }^{99}$ Minutes of the Iowa Conference . . ., op. cit., pp. 184-185.

${ }^{100}$ Minutes of the Trustees, October 18, 1852.

${ }^{101}$ Ibid., undated, between October 19, 1852 and April 1853.

${ }^{102}$ Ibid., October 19, 1852. 
have survived in the archives.

James Marshall McDonald was an 1851 graduate of Indiana Asbury University (now DePauw) and had been stationed at the LeClaire Circuit of the Iowa Conference in 1851. He served as president only until the spring of 1853 when he resigned for reasons of health. Stationed at Middletown, he died Sept. 12, 1853. His ties with the Institute continued through his brother, J. Wilbur McDonald who was graduated from Iowa Wesleyan in 1858, served as principal of the Academy 1860-1862, Professor of Latin and Greek 1862-1864 and as a trustee $1872-1893 .^{103}$

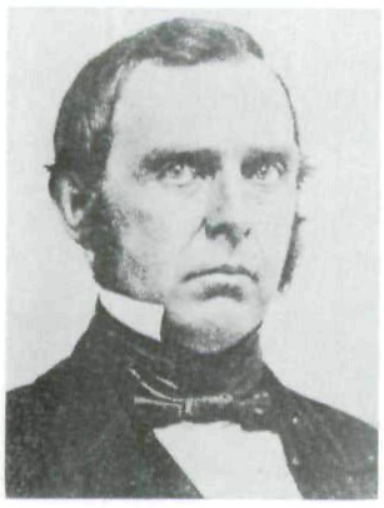

иерлен samer

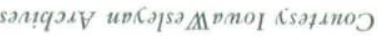

trustees were in negotiation ${ }^{105}$ - Harla indicated that he hat the no interest in becoming president of an academy and that the trustees should think in terms of a full collegiate program, a second building, and a stated salary for a president. The trustees accepted these suggestions and set the salary at $\$ 800$ a year. Harlan accepted this offer. At the same time the trustees engaged as a second teacher Elias Williamson Gray, a graduate of Augusta College, Augusta, Ky., with a B.A. and

${ }^{103}$ Cf. for biography, Louis A. Haselmayer, "James Marshall McDonald 1852-1853”, The Mount Pleasant News, March 25, 1967.

${ }^{104}$ For James Harlan, cf. Johnson Brigham, James Harlan, Iowa City, The State Historical Society of Iowa. 1913 (the official biography); The Dictionary of American Biography; Louis A. Haselmayer, "James Harlan" in The Encyclopedeia of World Methodism (forthcoming) which lists in detail his relations to Iowa Wesleyan and the Methodist Episcopal Church.

${ }^{105}$ Minutes of the Trustees, undated 1853; Brigham, op. cit., pp. 75-76. 
M.A. ${ }^{106}$ The Rev. Isaac I. Stewart was continued as agent ${ }^{107}$ and Harlan was requested to spend as much time as possible during the summer of 1853 in financial collections for a second building. On June 22, 1853, plans were made for the new building as the trustees determined on ". . . the collection of $\$ 15,000$ for the erection of additional college buildings \& the purchase of a good bell \& philosophical equipment" ${ }^{108}$

Harlan and Stewart devoted most of the summer of 1853 to fund raising which Harlan described in his Autobiographical Manuscript and Papers.

As I now remember, we received no one subscription which exceeded one hundred dollars; and very few of them so large. Many of them did not exceed five dollars each, and a considerable number were smaller than that. ... we proceeded steadily from day to day with our work of soliciting-chiefly by domiciliary visitation, making slow but steady progress during the summer and autumn. ${ }^{109}$

On Feb. 23, 1854, the trustees determined ". . . that we commence as soon as practical to erect a college building about $60 \times 100$ feet 3 stories high." ${ }^{110}$ A committee was appointed "to arrange the plan and procure a draft of the building" and suggestions were made to sell scholarships for this purpose. On March 6, 1854, the plans were revised to be a building ". . . 55 by 100 feet 3 stories high \& side front with cupola" and a committee was appointed to accept contracts. ${ }^{111}$ The contract was let by April 27, 1854, for $\$ 14,500$ to Alexander Lee of Burlington ${ }^{112}$ who was also a trustee and treasurer of the institution until Nov. 26, 1857. ${ }^{113}$ The cornerstone was laid with impressive ceremonies and an address by James Harlan on July 4, 1854, according to a detailed news account

${ }^{106}$ Minutes of the Trustees, April 1853. Historical Sketch and Alumni Record of Iowa Wesleyan University, Mount Pleasant, 1905, p. 23; Encyclopedeia of Methodism, ed. Matthew Simpson. Philadelphia, Everts \& Stewart, 1878 , p. 70.

${ }^{107}$ Ibid., May 30, 1853.

${ }^{108}$ Ibid., June 22, 1853.

${ }^{109}$ Brigham, op. cit., p. 77.

${ }^{110}$ Minutes of the Trustees, February 23, 1854.

${ }^{111}$ Ibid., March 6, 1854. The Mt. Pleasant Observer, March 28, 1854 contains an advertisement for contract acceptance on April 12. Cited in The Mt. Pleasant News, September 2, 1941, p. 2.

${ }^{112}$ The Mt. Pleasant Observer, April 27, 1854. Cited in The Mt. Pleasant News, September 2, 1941, p. 2.

${ }^{113}$ Minutes of the Trustees, November 26, 1857. 
in the Mt. Pleasant Observer. ${ }^{114}$ The work progressed during the summer and the walls were in position by early fall. But two destructive tornadoes on Sept. 21 and again on Oct. 2-3 blew down the north and east walls. ${ }^{115}$ The payments for the additional costs of rebuilding became the subject of endless wrangling in the meetings of the trustees until 1857. ${ }^{116}$ Some of the construction work on this building and all of the brick burning was done by Benjamin Franklin Pearson of Keosauqua, builder of the historic Pearson House. He was paid largely in scholarship deeds which his descendants later redeemed for tuition at Iowa Wesleyan. ${ }^{117}$ This building, still used today as Old Main, was ready for occupancy sometime in 1855 and lithographs of it appear on scholarship deeds as early as June 4, 1855, as well as in the Second Annual Catalogue 1855 .

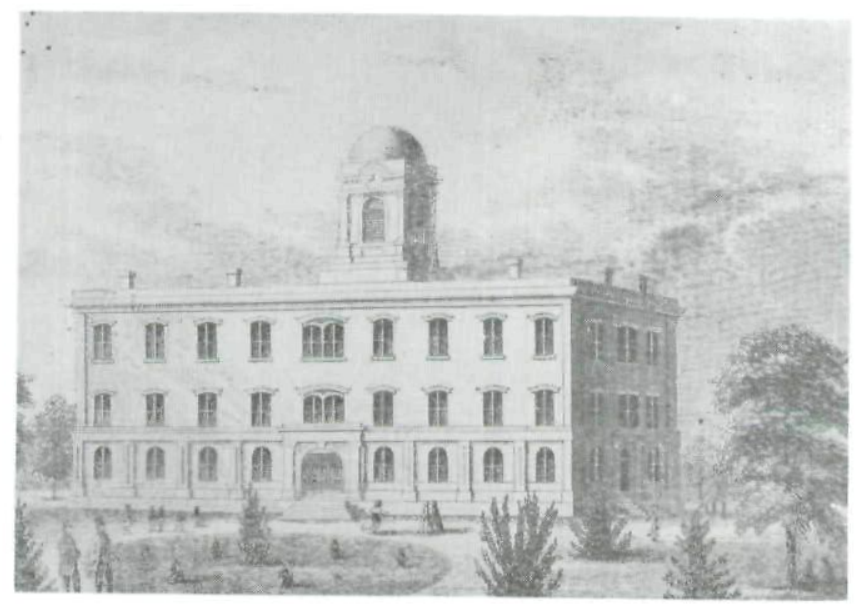

Courtesy Iowa Wesleyan Arcbives

\section{Old Main}

The academic year 1853-1854 was also devoted to the recruitment of a faculty, curricular changes and the preparation of advertisements of the Institute for the church press. A

${ }^{114}$ The Mt. Pleasant News, September 2, 1941, p. 2.

${ }^{115}$ The Mt. Pleasant Observer, September 26 and Oct. 6. Cited in The Mt. Pleasant News, September 2, 1941, p. 2.

${ }^{116}$ Haselmayer, 125th Anniversary History, op. cit., pp. 11-12.

${ }^{117}$ Ibid., p. 11. Cf. also Louis A. Haselmayer, "Letter", The Iowan Magazine, Summer 1966, p. 52. 
four year college program, devised by Harlan and Gray, was approved by the trustees on Feb. 23, 1854, and 500 copies of the First Catalog were ordered to be printed. ${ }^{118}$ This was a scanty little booklet, but the first official circular of the Institute. The collegiate program consisted of rather standard 19th century courses in Latin, Greek, mathematics, ancient and modern history with brief semesters of zoology, botany, physiology, chemistry, and geology. The senior year was devoted entirely to areas of political science and such theological subjects as natural philosophy, moral science, evidences of Christianity and a study of Butler's Analogy. The curriculum bears a striking resemblance to the 1840 plan of study of Indiana Asbury University, which Harlan knew at first hand. ${ }^{119}$

An important meeting of the trustees on Aug. 23, 1854, authorized a $\$ 5,000$ mortgage from John Hendree of Washington County, Iowa, to complete payment on Old Main, made the final decision on the sale of scholarship deeds for fund raising, set the terms of the college year, determined the degrees to be awarded by the Institute and appointed a college faculty. ${ }^{120}$ James Harlan was elected president and professor of intellectual philosophy and moral sciences; the Rev. Elias Williamson Gray, professor ancient languages; the Rev. George C. Whitlock, professor of mathematics and natural sciences and provision was made to appoint assistant teachers in the female department and for part time instruction in piano, drawing, French and German.

George C. Whitlock M.A. had formerly been professor of natural sciences at Genesee College, Lima, New York, which in 1850 had added a college department to the original Genesee Wesleyan Seminary, founded in 1831. Whitlock remained at Iowa Wesleyan until 1864 and was granted an honorary LL.D. in $1859 .{ }^{121}$

${ }^{118}$ Minutes of the Trustees, February 23, 1854. The First Annual Catalog of the Officers and Students of the Mt. Pleasant Collegiate Institute or Iowa Conference University, For the Year Ending August 25th, A. D. 1854. Mount Pleasant, M’Farland \& Wickersham, 1854.

${ }^{119}$ Haselmayer, 125th Anniversary History, op. cit., pp. 11-12.

${ }^{120}$ Minutes of the Trustees, August 23, 1854.

${ }^{121}$ Minutes of the Iowa Conference of the Methodist Episcopal Church, Annual Sessions 1854-1855-1856. Historical Society, South Iowa Conference, The Methodist Church, 1962, p. 34; The Encyclopedeia of Methodism, op. cit., p. 403. 
Louis Bechthold became a teacher of music; Mary A. Weir, preceptress; Friedrich Berchan Lucrode, a teacher of French, German and drawing; and Mr. J. B. Carnes and Miss P. J. Jenkins assistant teachers. ${ }^{122}$ These persons were chiefly on a part time basis.

\section{Student Enrollment Grows}

The full collegiate program was offered in the fall of 1854 . Enrollments began to rise; the earliest record, "The Register of the Mt. Pleasant Collegiate Institute, 1852-3," kept by the Rev. Thomas Corkhill, listed 66 students by name and the courses of elementary and secondary work for which they were enrolled. ${ }^{123}$ By the end of Harlan's first year the enrollment had risen sharply, for we read in a news item in The Keokuk Despatch for May, 1854, that "The fall session of the Collegiate Institute had an attendance of over 150 students." ${ }^{124}$ In the year 1854-1855, with the first college program under way, there was a freshman class of 25 with a preparatory group of 136 and a primary class of $57 .{ }^{125}$

Attempts were made to develop other areas of a university program, especially a Medical Department, in proposals set out on Feb. 15, 1855, ${ }^{126}$ to have a staff of six professors, three of whom would be local physicians, and a separate board of trustees. Late in 1855 it was announced that the Institute would be willing to locate this Medical Department in any Iowa community that would raise $\$ 10,000$. This policy seemed to have been inspired by the action of Indiana Asbury University (DePauw) in setting up the Indiana Central Medical College in Indianapolis in $1848 .^{127}$

On Feb. 3, 1854 plans were made to petition the State Legislature for a revised charter to change the name of the Mount Pleasant Collegiate Institute to Iowa Wesleyan University. ${ }^{128}$ The new charter, enacted on Jan. 25, 1855, was ac-

${ }^{122}$ The First Catalog, op. cit., p. 4; Minutes of the Iowa Conference. . . . op. cit., p. 34 .

${ }^{123}$ The Mt. Pleasant News, March 28, 1951, p. 2.

${ }^{124}$ Ibid., September 2, 1941, p. 2.

${ }^{125}$ Haselmayer, 125th Anniversary History, op. cit., p. 11.

${ }^{126}$ Minutes of the Trustees, Feb. 15, 1855.

${ }^{127}$ Haselmayer, 125th Anniversary History, op. cit., p. 12.

${ }^{128}$ Minutes of the Trustees, Feb. 3,1854. 
cepted by the trustees on Feb. 15, 1855. ${ }^{129}$ There exists in the archives of Iowa Wesleyan College a scholarship deed, dated March 15, 1855, on which the printed name, "The Mount Pleasant Collegiate Institute" has been crossed out and "Iowa Wesleyan University" written in by hand, a frugal method of using old forms for new situations.

With Feb. 15, 1855 the Mount Pleasant Collegiate Institute became history and Iowa Wesleyan University, with a full collegiate program established nine years after its first class in January, 1846, came into existence. This chapter of history was also the termination of James Harlan's presidency for he resigned on April 20, 1855, to become the first Republican Senator from Iowa to the United States Congress. ${ }^{130}$

In three years Harlan had saved a tiny preparatory school which had been on the verge of extinction, introduced a college program, gathered a faculty, erected a second building and effected a change in name. But his connection with Iowa Wesleyan University continued until his death and, in a sense, beyond that date as well, as is stated in The 125th Anniversary History of Iowa Wesleyan College.

Elected a trustee in 1855, he served until his death in 1899, acting as president of the board for 15 years. In 1855 he was elected Professor of Political Economy and International Law which he held until 1864 and again from 1870-1873, giving lectures when a resident in Mount Pleasant. In 1869-1870 he served as president and after his retirement from the Senate in 1873 devoted much time to university affairs. He was granted the title of Chancellor sometime before his death on October 5,1899 . The marriage of Harlan's daughter, Mary, to Robert Todd Lincoln, son of President Abraham Lincoln, provided a tie between Iowa Wesleyan and the Lincoln family. The university was designated an eventual heir of the Lincoln estate and the campus home of Harlan is maintained as a memorial museum today. ${ }^{131}$

${ }^{129}$ Act of Incorporation and Amendment, op. cit., pp. 5-8. "That the corporate name of the Mount Pleasant Collegiate Institute, located in Henry County, State of Iowa, be, and is hereby changed from Mt. Pleasant Collegiate Institute, to Iowa Wesleyan University. . . ."

${ }^{130}$ Minutes of the Trustees, April 20, 1855.

${ }^{131}$ Haselmayer, op. cit., p. 12. 
Copyright of Annals of Iowa is the property of State of Iowa, by \& through the State Historical Society of Iowa and its content may not be copied or emailed to multiple sites or posted to a listserv without the copyright holder's express written permission. However, users may print, download, or email articles for individual use. 